\title{
化學工學·化學機械學演習問題集 (II)
}

之は化學工學の理諭修得の第並儿計算の演㚙用として集めたるので全く基礎的なっののみである。

\section{3. 蒸叕}

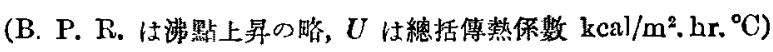

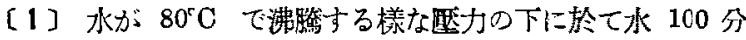
中に $\mathrm{NaOH} 45$ 分を含む溶液の沸點を推定せよ。但し次の如吉 データあり。

$\begin{array}{ccc}\text { 水 } 100 \text { 分中の } \mathrm{NaOH} & \text { 沸 點 }\left({ }^{\circ} \mathrm{C}\right) & \text { 整力 }(\mathrm{mmHg}) \\ 40.74 & 74.65 & 133.9 \\ 40.74 & 116.69 & 680.5 \\ 51.75 & 80.30 & 138.4 \\ 51.75 & 120.76 & 674.4\end{array}$

[2] $50.3 \%(\mathrm{w} t)$ の $\mathrm{CaCl}_{2}$ 水溶液に對して㻺力そ沸默との 閐係仕次垡の如くでする（Chem. Met. Eng., 1921，25)。之よ り Dühring's line を畫き絶對厴力 $739 \mathrm{mmHg}$ に於ける沸點 を求む。

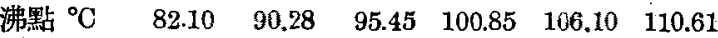
$\begin{array}{lllllll}\text { 厴 } \text { 力 }_{\mathrm{m}} & 112.9 & 162.4 & 202.6 & 253.0 & 311.6 & 371.3\end{array}$

〔3]nーオクタンの蒸氣㻺表（下記）を用ひて $120^{\circ} \mathrm{C}$ に於 ける蒸發潜熱 (kcal/kg) を求む。

$\begin{array}{lrrrrrrr}{ }^{\circ} \mathrm{C} & 50.6 & 66.0 & 83.5 & 94.8 & 103.9 & 111.4 & 117.5 \\ { }^{n}-\mathrm{C}_{8} \mathrm{H}_{28} & 50 & 100 & 200 & 300 & 400 & 500 & 600 \\ \text { 水 }^{\circ} \mathrm{C} & 38.11 & 51.57 & 66.45 & 75.89 & 82.96 & 88.68 & 93.52\end{array}$

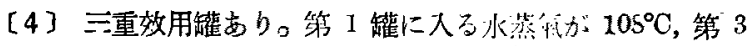
罐の黃空度は $667.4 \mathrm{mmHg}$ ( $50^{\circ} \mathrm{C}$ に相當す)でる。總括専熱 係數 Uは第 1,2,3 䌯の順に夫ぬ $2500,2000,1500\left(\mathrm{kcal} / \mathrm{m}^{2}\right.$.

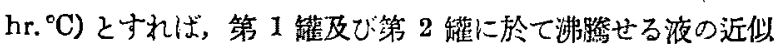
溫度如何。但し各罐共液の B. P. R. を無視し，加熱面積は等 しいとする。

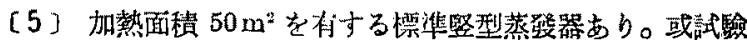
に於て 1 時間に $2500 \mathrm{~kg}$ の水蒸氣が凝縮した。蒸登窒內の医 力は $87.6 \mathrm{mmHg}$, 蒸莱室可は $400 \mathrm{mmHg}$ である。凝縮水は

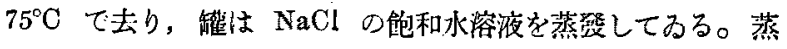
弱䌦の高さは $1.4 \mathrm{~m}$, 仅均液离は管頂上 $12 \mathrm{~cm}$ である。然らば 1) 見掛けの傳熱係数 2) BPR を補正せる你數 3 BPR 並

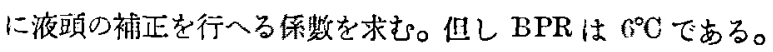

〔6] 單一效用雓にて固形分 $10 \%$ を含む有機コロイドを蒸 登仁依つて水分を除去して固形分 $50 \%$ に漊縮せんとす。 0.99 $\mathrm{kg} / \mathrm{cn}^{2}$ (ゲージ)のスチーム $\left(120^{\circ} \mathrm{C}\right)$ 岸加熱に用ひ, 蒸發空は 大氣盟 $760 \mathrm{~mm}$ に對し $660 \mathrm{mmHg}$ 直空に保つ。此櫛力は 50 ${ }^{\circ} \mathrm{C}$ に相當する。原料代込量は每時 $25,000 \mathrm{~kg}$, 見掛けの總括傳 熱係數は $2400 \mathrm{kcal} / \mathrm{m}^{3} . \mathrm{hr} .{ }^{\circ} \mathrm{C}$ 。凝縮水は $80^{\circ} \mathrm{C}$ で蒸發矱を去 り，溶液の B. P. R. は無視し得る。所要加熱面精及びスチー 么消費量を原料溫度が a) $50^{\circ} \mathrm{C}$, b) $20^{\circ} \mathrm{C}$, c) $90^{\circ} \mathrm{C}$ の時に就て 求めよ。但し原液の比熱は 0.00 , 蒸發潜熱は水に等しいとし, 輻射は無頙してよい。

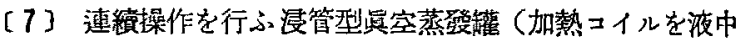
に浸した型)あり。液高を $1.2 \mathrm{~m}$ に保ち、コンデンサーに依り 異空度を $660 \mathrm{mmHg}$ (大氣劂 $=760 \mathrm{mmHg}$ ) に保つ。溫度 $20^{\circ} \mathrm{C}$ の $2 \% \mathrm{NaOH}$ 水溶液を每時 $50 \mathrm{CO} \mathrm{kg}$ 装入して，25\%溶液（比 望=1.3）を得んとす。加熱面積何程を要するか。但し，Uは $500 \mathrm{kcal} / \mathrm{m}^{2} . \mathrm{hr} .{ }^{\circ} \mathrm{C}$ とす。加熱用には目空庭 $150 \mathrm{mmHg} \sigma$ 嘚

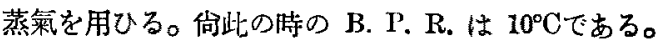

$\begin{array}{lll}120 & 122.8 & 125.59\end{array}$

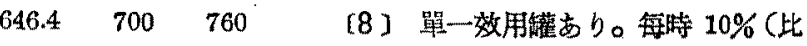

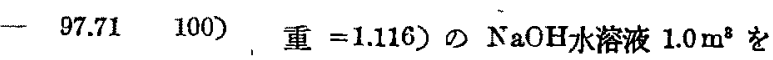
$50 \%$ (比重 $=1.54$ ) に者つめたい。原液は $20^{\circ} \mathrm{C}$ で入り加熱蒸

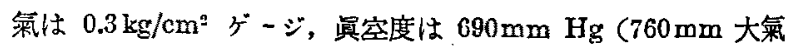

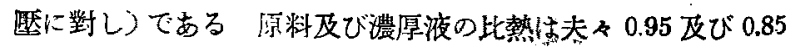
で, $50 \% \mathrm{NaOH}$ 溶液の BPR は $15^{\circ} \mathrm{C}$ である。份濃厚液は沸 點で，登櫵を去り，㠜樎水は $0.3 \mathrm{~kg} / \mathrm{cm}^{2}$ ゲージの飽和溫度で去 り，總括傳熱俰数を. $1100 \mathrm{kcal} / \mathrm{m}^{2} . \mathrm{hr},{ }^{\circ} \mathrm{C}$ とする時 a) 加熱面 積 $\left.\mathrm{m}^{2} \mathrm{~b}\right)$ 加熱水蒸氣量 $(\mathrm{kg} / \mathrm{hr})$ 夫多如何。

[9]二西蒸發罐に依つて 5\%のコロイド溶液 $10,000 \mathrm{~kg} / \mathrm{hr}$ を演縮し $25 \%$ 溶液を得たい。原料は $80^{\circ} \mathrm{C}$ で給液法は順流とす る。第 1 蠸の加熱コイルには $110^{\circ} \mathrm{C}$ で㠜縮する飽和水蒸氣を 用ひ，第2蠸は液が $50^{\circ} \mathrm{C}$ て沸䏲する樣な真空度を保つてる る。各罐の加熱コイルの凝縮液は直に系から取出す。然らば次 の諸項夫ふ如何。但し各罐の加熱面積は同一とし，周園への熱 損头は筧視する。原料液の比熱は 0.95 , 各䠰に於ける BPRは 
無視し，Uは第 1，第2知に於て夫ネ 2000 及び $1000 \mathrm{kcal} /$ hr. $\mathrm{m}^{\mathrm{a}}{ }^{\circ} \mathrm{C}$ とす。
a) 第 1 罐に供給する加熱蒸氣量 $(\mathrm{kg} / \mathrm{hr})$
b) 第 1 鑵の沸點
c) 各蠸の加紮面程
d）第 1 罐に於ける每時の蒸發水量
e）若し原料溫度か: $10^{\circ} \mathrm{C}$ の場合の上記諾量

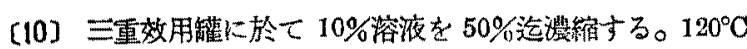
の能和水蒸氣を用ひて加熱を行ひ，第 3 罐の篜發空は $660 \mathrm{~mm}$ $\mathrm{Hg}$ の䓂空 (大氧 $760 \mathrm{mmHg}$ ) に保つ。原料は $20^{\circ} \mathrm{C}$ で每時 $25,000 \mathrm{~kg}$ 裝入し，凝縮水は各權を㠜縮溫度で去る。溶液の $\mathrm{B}$. P.R. は無視し得，之の比熱は各濃度に於て 1.60 と假定する 且各嚇の加熱面積は相等しく，給湤法は順流にして傳熱保數は 第1-2 3 壦の順に夫之 $2700,1700,1000$ とする。a）此の時 加熱面積，加熱蒸氣量，水蒸莱 $1 \mathrm{~kg}$ 當りの蒸發水量を求めよ。 又若し b) 第 2 䌯加ら每時 $2000 \mathrm{~kg}$ の蒸氣を抽氮する場合に 如如何。

[11] 某蒸登器の操作條件次の如し。

給液：5\%固形分を含屯溶液每時 $20,000 \mathrm{~kg}$, 濃厚液: 固形分 $50 \%$, 水蒸氣 : $120^{\circ} \mathrm{C}$, 給液温度 $95^{\circ} \mathrm{C}$, 凝縮器に於ける蒸發氣の.

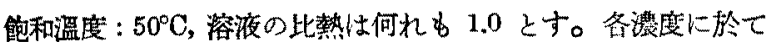

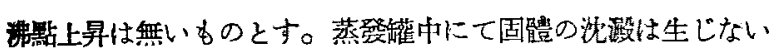
ののとす。輻射による熱損失は無視する。凝樎夜は几て凝縮溫 度で去り，多重效用の場合各效用內の加熱面㧼は等しとす。 然る時下記の場合に就て次の $a, b, c$ 三項を求む。

a) 效用矱 1 個に對する加熱面積 $\left(\mathrm{m}^{2}\right)$

b) スチーム消費量 $(\mathrm{kg} / \mathrm{hr})$

c) スチーム, $1 \mathrm{~kg}$ 當りの蒸發水量

I. 單一效用 : $U=3500$, II. 二重效用 (順流供給)： $U_{\mathrm{I}}=3700$, $U_{\mathbf{n}}=3800$, III. 三重数用（順流供給）: $U_{\mathrm{I}}=3500, U_{\mathrm{II}}=3300$, $U_{\text {III }}=3000$

[12]前題と全く同樣な場合に於て, 液が相黨の B, P.R.の ある場合に就き同し計算を絽返甘。

\begin{tabular}{|c|c|c|c|}
\hline I, 單一效 用 & $U=3500$ & & $=14^{\circ} \mathrm{C}$ \\
\hline II. 二重效用(䐓流) & $V_{\mathrm{I}}=3700$ & " & $=0^{\circ} \mathrm{C}$ \\
\hline & $U_{I I}=3300$ & " & $=14^{\circ} \mathrm{C}$ \\
\hline III. 三重效用(順流) & $U_{I}=3500$ & " & $5^{\circ}$ \\
\hline & $t_{\mathrm{rI}}^{\nu}=3300$ & $"$ & $7^{\circ}$ \\
\hline & $\boldsymbol{U}_{\mathrm{III}}=3000$ & $"$ & $=14^{\circ}$ \\
\hline
\end{tabular}

但し $U$ は B.P.R,た對して補正したる傳熱俰數とする。

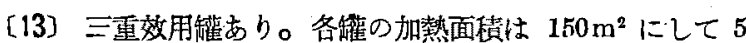

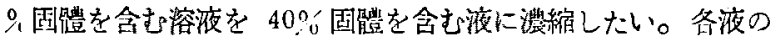
B.P.R.は無就し得る。5\%液は $80^{\circ} \mathrm{C}$ で罐に入る。 $40 \%$ 液は非 常に粘稠度る故 II - III I 方順に錯流供給を行ふ。加熱蒸氣 は $120^{\circ} \mathrm{O}$, 最終罐は溫度 $40^{\circ} \mathrm{C}$ に相虽する鿓空に保つものとす る。Uは夫及Iに於て 1500 , II に於て 2500 , III に於て 2000 とし溶液の比熱はすべて 1.0 とする。加熱用蒸氣はすべ てその㠜縮溫度て䌯を去るものとし，輻射による熱損失は無视

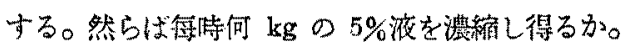

〔14〕二重效用罐の第 1 罐の加熱コイルに $120^{\circ} \mathrm{C} の$ 飽和水蒸

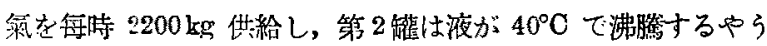
な罢空度に保つてある。 $T$ は㴘度差 $\Delta t\left(^{\circ} \mathrm{C}\right)$ に比例し，液の粘 度 $\mu$ (センヂポイ゙)に逆比例するものとし $U=440 \Delta t / \mu$ $\left(\mathrm{kca} / \mathrm{m}^{2} . \mathrm{hr} .{ }^{\circ} \mathrm{C}\right)$ て裴はされる。初めの罐を通過した夜は次の 如き粘度を有す。

$\begin{array}{llllllllll}t^{\circ} \mathrm{C} & 40 & 50 & 60 & 70 & 80 & 90 & 100 & 110 & 120\end{array}$ $\begin{array}{lllllllll}\mu \text { c.p. } 3.28 & 2.75 & 235 & 2.03 & 179 & 1.59 & 1.42 & 1.29 & 1.17\end{array}$ 製品の粘度は各溫度に於て夫々上記の 20 倍の粘度を有与る。 然らば a) 各罐の加熱面積が等しいとして順流及び逆流各給液 法の場合の總加熱面積を求む。又 b) 全加熱面積を最小ならし むるには备罐の面積を如何にすれ社よいか。順流，逆流の夫ゃ 以就て之を求む。但し B.P.R. 及ゔ㬏射熱損失を無視し，液は 齐䌯に其の沸點でるものとする。

[15] $50 \%$ NaOH 水溶液を得るため, 從來の蒸發罐をそ のま」使用し，操作條件を縋へたところ蒸發量は前上り $15 \%$

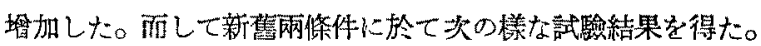
然らば 1)备々の場合に於ける沸騰夜の平均溫度 2) 冷却用 水所要量の比 3) 原料供給量の比 4) Uの變化率 5) スチー 么消費量の變化率等を求む。但し各場合に於て冷原料は䌯に入

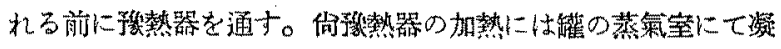
縮せる凝繀水を使用寸る。

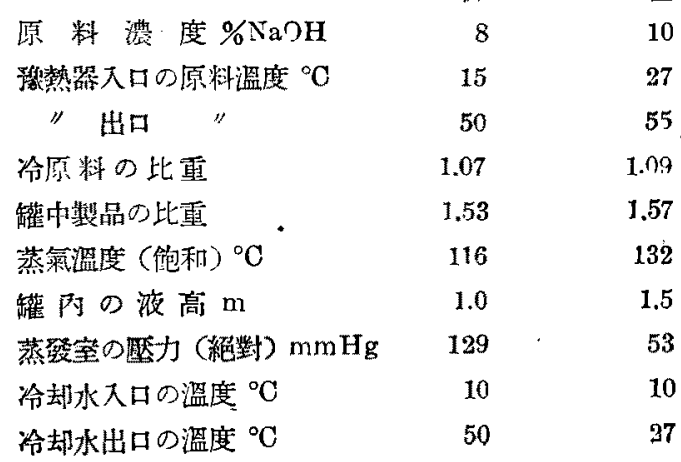




\section{凝樎器を去る液溫 ${ }^{\circ} \mathrm{C}$} 過熱蒸氣の比熱

\section{4}

0.46

32

0.46

〔16]單一效用罐にて氷 $100 \mathrm{~g}$ に對し $\mathrm{NaOH} 11.1 \mathrm{~g}$ を含も 原料加水 $100 \mathrm{~g}$ に對し $\mathrm{NaOH} 150 \mathrm{~g}$ を含む溶液を得てる る。今加熱蒸氣の壓力を高くし且蒸登室の资空度を高めたとす

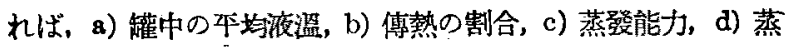
氣消費量の變化夫ょ如何。但し新舊の作業條件は下記の如し。

\begin{tabular}{|c|c|c|}
\hline & 舊 & 新 \\
\hline 原液温度 & $40^{\circ} \mathrm{C}$ & $40^{\circ} \mathrm{O}$ \\
\hline 䌯中の液高 & $1.2 \mathrm{~m}$ & $1.2 \mathrm{~m}$ \\
\hline 加熱蒸氣溫度 & $150^{\circ} \mathrm{C}$ & $170^{\circ} \mathrm{O}$ \\
\hline 蒸發室の智力 & $200 \mathrm{mmHg}$ & $75 \mathrm{mmHg}$ \\
\hline 維液の比重 & 1.60 & 1.55 \\
\hline 原液の比央 & 1.12 & 1.12 \\
\hline
\end{tabular}

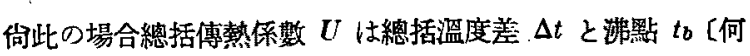
れも゚元との間に次の如き關係にある。

$$
U=39 e^{\frac{\Delta t}{b s+17.8}}[\Delta l(t s+17.8)]^{0.4}
$$

溶解熱は無悓し、 $\mathrm{NaOH}$ 水溶液の沸點は次表の如しとす。 $\mathrm{NaOH}$ 水溶液の沸點

\begin{tabular}{ccc}
$\% \mathrm{NaOH}$ & $25 \mathrm{mmHg}$ & \multicolumn{2}{c}{$\begin{array}{c}260 \mathrm{mmHg} \\
0\end{array}$} \\
0 & 26.7 & 100.0 \\
10 & 27.8 & 102.8 \\
20 & 31.7 & 107.0 \\
30 & 39.7 & 116.7 \\
40 & 51.7 & 130.3 \\
50 & 65.0 & 144.3 \\
60 & 79.4 & 159.7
\end{tabular}

〔17〕 2 個の大きさの異る矱より成る二重效用矱に於て溶質 不明の $5 \%$ 水溶液を處理して比重 1.25 の $80 \%$ 水溶液を每時 $4.0 \mathrm{~m}^{3}$ 得たい。第 2 䌯は第 1 蠸より蒸發量が多く蒸發蒸氣量 として $8 \%$ (重量) だけ多い。而して第1䠰には低濃度の原料 を供給し，加熱蒸氣は $150^{\circ} \mathrm{C}$ (飽和) で第 2 鑵に入り，(郎ち逆 流供給)，罐を去る凝縮水は原料を $20^{\circ} \mathrm{C}$ から $40^{\circ} \mathrm{C}$ に哠熱す るのに用ひる。第 1 蠸の蒸發室は全壓 $75 \mathrm{mmHg}$ に保つ。静厴

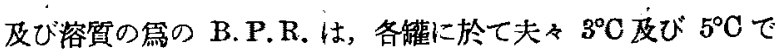
古る。然らば 1) 毎時の原料供給量 (kg) 2) 每時の全蒸發水量 3）加熱蒸氣淮費量 (kg/hr) 4) 各㓋に於ける加熱面積 5) 各罐 に於ける液の沸點 6) 第2罐に於ける蒸發氣の㑛力等を求む。 但し此の場合傳熱係數 $U$ は總括溫度差 $\Delta\left({ }^{\circ} \mathrm{C}\right)$, 溶液の沸黣 $t$ $\left({ }^{\circ} \mathrm{C}\right)$, 溶解物の百分等 $r$ と次の如き验式にて表はされる。

$$
U=1950\{\Delta /(t+17.8)\}^{1 / 2(1 / r)^{1 / 3}}
$$

[18]單一效用䠰にてグリセりンの包收を行ふっ。原液は每時
$20 \mathrm{~m}^{8}$, (比重 $=1.03$ )，濃度 $5 \%$ (重量)，溫度 $10^{\circ} \mathrm{C}$ であるが， 之は後に述べる表面凝縮器で，先ず $60^{\circ} \mathrm{C}$ に预熱され，更に加 熱室安出る蒸氟の凝縮水に体て殆ど蠸內の本均沸點近く $\left(3^{\circ} \mathrm{O}\right.$

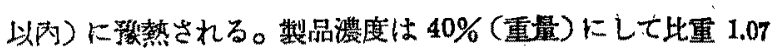
である。罐內の液高は $90 \mathrm{~cm}$ に保ち此の境合總括傳熱便數は $2000 \mathrm{kcal} / \mathrm{hr} . \mathrm{m}^{2} .{ }^{\circ} \mathrm{C}$ である。カランドリヤに入れる加熱蒸氣は 溫度 $150^{\circ} \mathrm{C}$, 過熱度. $15^{\circ} \mathrm{C}$ の過熱蒸氣である。此の凝縮液は前 記の第 2 湤熱器の加熱用とする。更に本裝置には表面凝縮器及 びジェットコンデンサーを直列に接繶しですり，第1の表面㠜 縮器は前述の如く同時に原料の第 1 預熱器の役目をしてるる。 而してここでは蒸發氣の過熱を除去し，一部を凝縮せしめて， （本器內の總括傳熱係数は $6000 \mathrm{kral} / \mathrm{m}^{2} . \mathrm{hr} .{ }^{\circ} \mathrm{C}$ ) 次のジェット

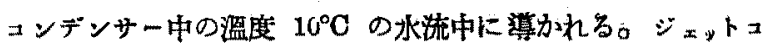
ンデンサーを去る最後の混合液の溫度は $30^{\circ} \mathrm{C}$ でする。斯くて

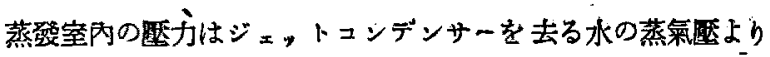
500\%大であつた。然らば次の諸項如何。

1) 雉內液の本均沸點 2) 加熱蒸氣量 $\mathrm{kg} / \mathrm{hr}$ 3) カランドッ

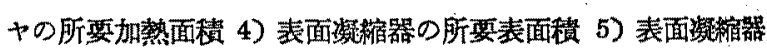
內にて瀑缩する蒸氣の割合 6) ジェットコンデンサーに循環す

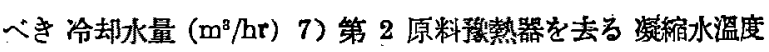

[19] 大規模蒸溜水辋造用蒸登權あり。綜合效率 $60 \%$ \%

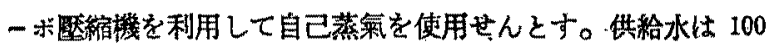

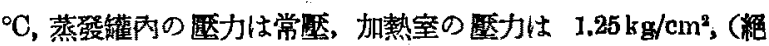
對)で操作すればよい樣な加熱面積を有す。輻射熱損失を無視 し得るとし，每時 $50 \mathrm{~m}^{\mathrm{a}}$ の蒸溜水を作るには所要動力如何。

[20]或蒸發罐に於て運轉中次第にスタール为泭着し，4時 間後に傳熱你数が 2630 となり，12 時間後に2:10に下つた。 然らば 48 時間後及び運轉開始時の伱數は夫々何程か。”

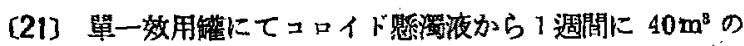

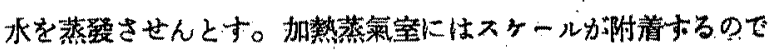
掅除の窎 1 遇間に一度 6 時間運轉を休止する。. 掃除の直前には $U$ が 250 に下るが掃除後 1 時間目には 120であつだ一旦 附着せるスケールは運轉中には剝落する事なしとし，且えヶー ルのたまり方は全傳熱量に比例するすのとする（斯かる場合に は $1 / U^{2}=a+b \theta$ で表はされる)。然らば次の諸項如何。

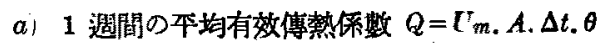

b) 1 邀間に 2 包掃除するとすれば 1 淍間の蒸發水量如何。

但し掃除には同じく 1 包にうき 6 時間を要し，掃除から㧫除 迄の間隔は等しくする。

c）蒸發水量を最大ならしむるには連續運轉時間何程がよい か。又その時の蒸發何程か。 


\section{4. 空氣調濕及び乾燥}

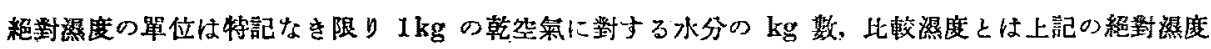

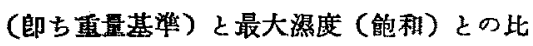

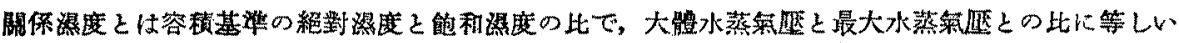

D. B. は乾量基準の略, W. B. は湿量基準の略

〔1]溫度 $50^{\circ} \mathrm{C}$, 比較濕度 $50 \%$ の空氣あり。之の紿對濕度， 點及び缹潤比容を求さ。

[2] $70^{\circ} \mathrm{C}, 1$ 氣歷に於て關係濕度が $70 \%$ の空氣の比較涂度

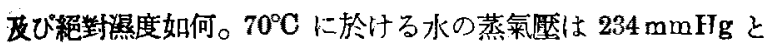
†る。

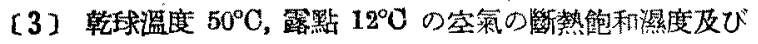
湜域㯰度を求む。

[4] $20^{\circ} \mathrm{C}$ に於て比較濕度 $50 \%$ の室氣を $70^{\circ} \mathrm{C} に$ 预熱し た。旅熱前後の濕球盟度及び比較湿度を表示せよ。

（5] 或建物內の空氣を罝度 $20^{\circ} \mathrm{C}$, 濕度 $50 \%$ に保ちたい。 その第に空氣を噴籍音に通して冷却し，次に噴霧空を出た空氣 を $20^{\circ} \mathrm{C}$ 迄加熱するといふ操作による。然らば噴露窒に大る宾 氣が $30^{\circ} \mathrm{C}, 70 \%$ 0時, 噴霧窒に於ては乾燥室氣 $1 \mathrm{~kg}$ につ何 kg の水が蒸發又は㠜縮するか。又噴露室に入れる水の溫度は 最高何度迄許し得るか。

（6〕寒䁔計にベンゾールで需らした布を卷きつけ，之に溫 度 $40^{\circ} \mathrm{C}$ の乾燥ガスを吹きつけたならば，寒援計は何度を示す 加。

〔7〕全壓 $760 \mathrm{~mm}$ に於て空氣一エチルアルコール系の濕度

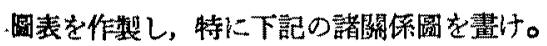

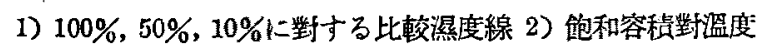
3) アルェールの蒸發潜熱對溫度 4) 濕潤比熱對濕度 5) 㴊熱 能和盢度 $10^{\circ}, 30^{\circ}, 50^{\circ} \mathrm{C}$ 對寸る欮熱冷却線 6) $10^{\circ} \cdot 30^{\circ} \mathrm{C}, 50$ ${ }^{\circ} \mathrm{C}$ 下對寸る乾㬎球㯰度線

データ: アルコール蒸氣の比熱 $=0.35$ 宾氣ーアルコールに對する $h / k a^{\prime}=0.40$

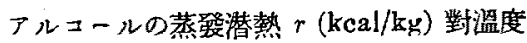
$\begin{array}{lllllll}{ }^{\circ} \mathrm{C} & 20 & 40 & 60 & 78.3 & 100 & 120\end{array}$ $\begin{array}{lllllll}r & 218 & 215 & 210 & 204 & 194 & 181\end{array}$ フルコールの蒸氣塺對温度

${ }^{\circ} \mathbf{C}$

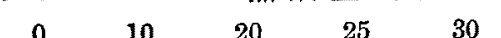
$\begin{array}{lllllll}\mathrm{mmHg} & 12,2 & 23.6 & 439 & 59.0 & 78.8 & 103.7\end{array}$
[8] 乾燥表面積 $60 \mathrm{~m}^{2} /$ ton なる多孔性固體 1 ton を乾燥固 體 $1 \mathrm{~kg}$ に對して $0.1 \mathrm{~kg}$ 水分より $0.01 \mathrm{~kg}$ 迄乾燥せしむ。乾燥 に要する時間を求む。但し平均乾燥速度を $1 \mathrm{~kg} / \mathrm{m}^{2} . \mathrm{hr}$ とす。

[9]縱横各 $1.0 \mathrm{~m}$, 厚さ $50 \mathrm{~mm}$ の板狀のものを定常乾燥狀 態で水分 50\%から 2\%まで乾燥する。材料の密度は乾きたる狀 態で $500 \mathrm{~kg} / \mathrm{m}^{z}$, 試擥の結果によれば含水量 $50 \%$ より $25 \%$ の間

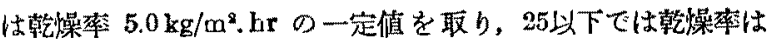
減少した。材料の平衙水分は殆ど 0である。所要の乾燥時間は 何程か。(含水量は何れす濕量基準とする)

[10]一定㢹菜條件に於て $36 \%$ 水分の固體が 5 時間後に水 分 $8 \%$ になつた。臨界水分は $14 \%$ ，平衙水分は $4 \%$ でる。然 らば同じ鞋懆㣠件で $8 \%$ 水分から $5.5 \%$ 水分にするには何時間 を要するか。但し水分はすべて乾量基隻郎ち乾燥固體 $100 \mathrm{~kg}$ に對する水量を $\mathrm{kg}$ で表はしたものである。

(11) 或翰焻器に於て每時 $100 \mathrm{~kg}$ の水を壆發させるのに使 用する室氣は瀑度 0.0100 , 溫度 $23^{\circ} \mathrm{C}$ でる。，之を $70^{\circ} \mathrm{C}$ に瑔 熱して乾燥器に入れる。乾燥器を去る宾氣は乾球溫度 $54^{\circ} \mathrm{O}$, 茲 球溫度 $38^{\circ} \mathrm{C}$ である。所要空氯量 $(\mathrm{kg} / \mathrm{hr})$ を求む。

[12]㩰熱乾燥により每洔 $500 \mathrm{~kg}$ の水分を蒸發させたい。

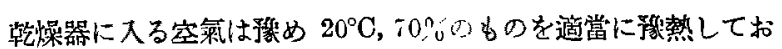
く。乾燥器を去る空氣は $40^{\circ} \mathrm{C}, 95 \%$ である。然らば a) 每時の

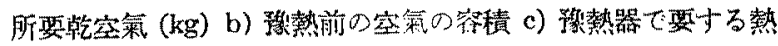
量 (kcal/hr) を求む。

(13) 水分 $50 \%$ (D.B) t含む温度 $40^{\circ} \mathrm{C}$ の濕潤材料每時 500 $\mathrm{kg}$ を水分 $5 \%$ 迄乾燥せんとす。此の第溫度 $65^{\circ} \mathrm{C}$, 濕度 0.0156

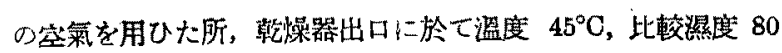
\%となつた。然らば a) 颙燥器に入る空氣悔時幾 $\mathrm{m}^{3}$ なるか。 又 b) 乾燥器の前に预熱器を置き, 预熱前の效氣が $25^{\circ} \mathrm{C}$ であ れば预熱器に供給すべき熱量 (kcal/hr) 如何。c) 憱燥器の入口 
及び出口の空氯の濕球温度如何。

[14]乾球 $18^{\circ} \mathrm{C}$, 濕球 $13^{\circ} \mathrm{C}$ の空氣を $90^{\circ} \mathrm{C}$ に预熱した後影 煤器に入れた所, 出口に於て比較濕度が $95 \%$ となつた。外部 への熱損火繁しとして次の諸項を求さ。a) 乾燥器出口の空氣 溫度，b)此の宾氣 $1 \mathrm{~m}^{3}\left(18^{\circ} \mathrm{C}\right)$ に体て蒸發される水量，c) 妤 熱器て $120^{\circ} \mathrm{C}$ に加熱しておいた場合の a) 及び b), d) c)に必 要な预熱器に供給すべき熱是，e）a）て求めた樣な䁅度で乾燥

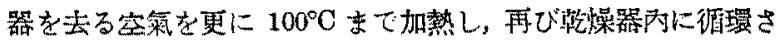
せれば此の空氣 $100 \mathrm{~m}^{3}$ に依つて蒸發される水量。

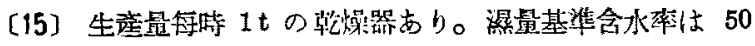
ソより15\%に減ぜらるるに反し，室気の濕度は0.0100より

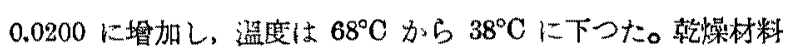
は $28^{\circ} \mathrm{C}$ で入り，同温度で出る。然らば周園への熱損失 $\left(\mathrm{kca}^{\prime} /\right.$ br) 如何。 $28^{\circ} \mathrm{C} k$ 於て水の蒸發潜熱は $581 \mathrm{kcal} / \mathrm{kg}$, 乾空氣の 比熱 $=0.24$, 水蒸莱の比熱は 0.46 とす。

〔6〕向流式回轉乾燥器に上り水分 $50 \%$ を含む秒を水分 3 \%迄乾曒する。草燥器に入る空氣は盢度 $104^{\circ} \mathrm{C}$, 濕度 0.007 で, 砂は $20^{\circ} \mathrm{C}$ こ入り $36^{\circ} \mathrm{C}$ て出る。出口空氣溫度は $38^{\circ} \mathrm{C}$, 濕り砂 の䢪入量は每分 $600 \mathrm{~kg}$ である。輻射による熱䠗失は乾燥空氣 $1 \mathrm{~kg}$ につ $5 \mathrm{kcal}$ でする。乾爟器を通造する乾燥空氣の $\mathrm{kg}$ 數及び乾燥器を去る空氣の湿度を求屯。低し $20^{\circ} \mathrm{C}$ 下於ける水 の蒸發潜熱は $585 \mathrm{keal} / \mathrm{kg}$, 乾砂の比熱は 0.21 , 茫攻氣の比熱は 0.24, 水蒸氮の比熱主 0.46 と寸る。

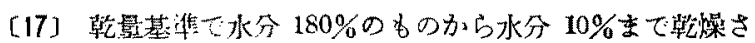
せたい。之に用ひる空乘は溫度 $20^{\circ} \mathrm{C}$, 絕對濕度 0.010 である

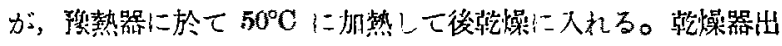
口では溫度 $45^{\circ} \mathrm{C}$ ，比較濕度 $70 \%$ 上なつた。䩚畑材料の熱容量 を無視して粼品 $1000 \mathrm{~kg} / \mathrm{hr}$ 二つ承次の諸項を求む。材料の溫 度は $40^{\circ} \mathrm{C}$ とする。

a) 预熱器に入る空乘量 $\left(\mathrm{m}^{n} / \mathrm{hr}\right)$ b) 乾燥器に入る空氣 $\left(\mathrm{m}^{3} /\right.$ br) c) 预熱器で加へられる熱量 $(\mathrm{kcal} / \mathrm{hr})$ d) 畭操器队で加 ふべき熱量 e) 蒸登水 $1 \mathrm{~kg}$ につき要寸る全熱量 f) 矠熱器 入日, 乾燥器の入口及び仙口に於ける空筑の乾球溫度, 濕球 盢度及少露點。

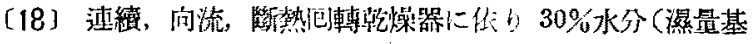
淮）を含む結晶加号 $2 \%$ 水分の結晶を每時 $1000 \mathrm{~kg}$ 得たい。乾 燥器に入る空菉は乾球 $110^{\circ} \mathrm{C}$, 濕球 $40^{\circ} \mathrm{C}$, 乾燥器を去る空氣は $48^{\circ} \mathrm{C}$ である。絬晶が小さいので許し得る最大空篓速度は斷面
耤 $1 \mathrm{~m}^{2}$ 䓨り靯燥空氣として每時 $3000 \mathrm{~kg}$ である。此の場合 a) 所要乾燥空氣量 $\mathrm{kg} / \mathrm{hr}$; b) 乾懆器の断面積 $\mathrm{m}^{2}$ を求け。

[19] $12 \times 20 \times 4 \mathrm{~m}^{3}$ の堂の室氣を 2 分間每に取換へて溫度 $20^{\circ} \mathrm{C}$, 潜度 $40 \%$ に保ちたい。户外の空氣は温度 $0^{\circ} \mathrm{C}$, 濕度は趋 だ低く０と見なしてよい。若し溫濕の調篩を單に室氣を加熱 し，然る後所要の條件まで增濕する事のみに依つて行はんとす れば室氣を何度迄加熱すべきか。又その際の賁霧室の容積如 何，但乙 $h a=14.00 \mathrm{kcal} / \mathrm{m}^{8}, \mathrm{hr} .{ }^{\circ} \mathrm{C}$ とする。

又室氧を预熱し次で $95 \%$ に罾濕し然る後所要の條件汽加熱 するならば此の操作は如何に行ふぺきか，且又噴籍室の容視㠰 何。又备々の加熱器に於て $0.3 \mathrm{~kg} / \mathrm{cm}^{2}$ ゲージの水蒸氣を用ひる

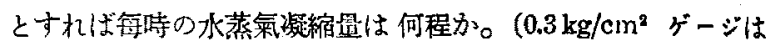
$107^{\circ} \mathrm{C}, \mathrm{r}=535 \mathrm{kcal} / \mathrm{kg}$ )

[20] 或强制通風冷却塔に就て下記の成績を得た。之により a) 荅に大る空氣量 $\left(\mathrm{m}^{2} / \mathrm{hr}\right)$ 及び (b) 傳熱䋆數 $h a$ 安求む， 供給水量 $=150 \mathrm{~m}^{\mathrm{3}} / \mathrm{hr}$ 出口空氣蒸度 $=0.031$ 大口水溫 $=43.5^{\circ} \mathrm{C}$ 入口空氣榅庭 $=28^{\circ} \mathrm{C}$ 出口” $=32.5^{\circ} \mathrm{C}$ 出口" $=35^{\circ} \mathrm{C}$ 入口空氣濕度 $=0.012$ 塔 容 積 $=63 \mathrm{~m}^{3}$

[21]容積 $62 \mathrm{~m}^{\mathrm{a}}$ の冷水塔に於て次の如き試驗結果を得た。 塔項に入る水溫， $40.6^{\circ} \mathrm{C}$ 塔底を去る水温 $29.2^{\circ} \mathrm{C}$ 荅底に入る室氣溫度 $21.7^{\circ} \mathrm{C}$ 塔頂を去る室氣溫度 $32.2^{\circ} \mathrm{C}$ 塔底に入る空氣濕度 0.0662 塔頂を去る室氣濕度 0.0295 塔に入る空氣量 $95,000 \mathrm{~m}^{8} / \mathrm{hr}$ 水量 $160 \mathrm{~m}^{8} / \mathrm{hr}$ 若し空氣が $40^{\circ} \mathrm{C}$ 迄上䒜寸るならば水は何度迄冷却される か。但し水及び窒氣の量，並に㬎度は不變とす。

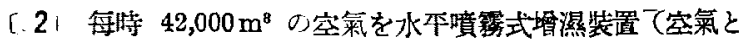

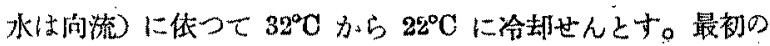
空氣濕度は $0.011 \mathrm{~kg} / \mathrm{kg}$ dry air。蒸發されない水は裝置內で

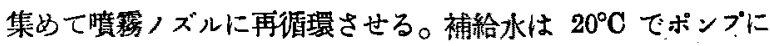
入る。然る時 a) 噴霛空の断面積 $\mathbf{m}^{2}$, b) 每時僨出される水 量 $\mathrm{kg} / \mathrm{hr}, \mathrm{c})$ 每特の補給水量 $\mathrm{kg} / \mathrm{hr}$, d) 噴露室の長さ $\mathrm{m}, \mathrm{e}$ )

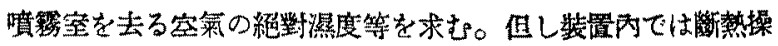
作が行はれるとし，壓力はすぺて 1 atm とする。向 1 試驗成綪

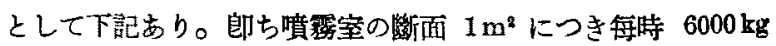
の水を噴䈃させ，乾燥空氣として $12,000 \mathrm{~kg} / \mathrm{m}^{2} . \mathrm{hr}$ を用ひた時 總括俅熱係数「aは $1400 \mathrm{kca} / \mathrm{hr} .{ }^{\circ} \mathrm{C}, \mathrm{m}^{3}$ (室)であつた。

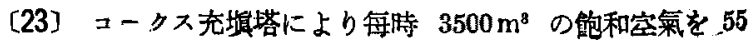


${ }^{\circ} \mathrm{O}$ から $18^{\circ} \mathrm{C}$ に冷却したい。操作は $1 \mathrm{~atm} て ゙$ 行はれるとし， 命却水は $13^{\circ} \mathrm{C}$ で入り， $43^{\circ} \mathrm{C}$ まで戒して差支へない。ガス速

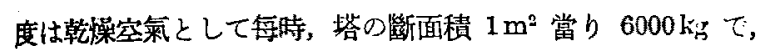
水量は $5600 \mathrm{~kg} / \mathrm{hr}$. m² であ。

所要の塔の直豝及ひ高さ，並に每時の冷却水量を計算世上。

[24]トンネル乾燥器 (斷熱)によつて板狀物の水分を 100

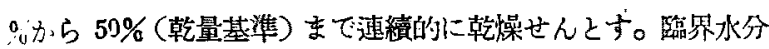
40\%, 本衡水分 $5 \%$ (影基基準)である。板は本均 $180 \times 60 \times$ $06 \mathrm{~cm}^{3}$ で兩面から乾燥される。濕り板 1 枚は $6.8 \mathrm{~kg}$ である。 溔球温度 $27^{\circ} \mathrm{C}$ の空氣が $56^{\circ} \mathrm{C}$ で乾懆器に入り， $32^{\circ} \mathrm{C}$ で去る。 室氬は板の面に本行に流れその速度は平均 $16,000 \mathrm{~kg} / \mathrm{hr} . \mathrm{m}^{2}$ (板 々板の間の空間面栍)で傳熱你数は $20 \mathrm{kcal} / \mathrm{hr} . \mathrm{m}^{2} \cdot{ }^{\circ} \mathrm{C}$ で甶る。 大の和求む。

a) 乾燥時間 (hr) b) 平行な2枚の板の間の断面楀(ここを 室氣が流九る) が $180 \times 2.5 \mathrm{~cm}^{2}$ として每時の所要乾燥室氣量 (kg) 及び空氣が直列に流れる板の數。

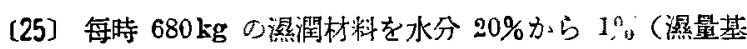
準)下乾燥せんとす。溫度 $20^{\circ} \mathrm{C}$, 濕度 $50 \%$ の新鲜空氣を乾燥

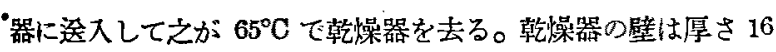
$\mathrm{mm}$, 熱傳導率 $0.15 \mathrm{kca} / \mathrm{m} . \mathrm{hr} .{ }^{\circ} \mathrm{C}$ の保溫板より成る。然らば 乾燥器の壁で水分の筑樎が起らない程度の最小所要空氣量は每 特幾 $\mathrm{m}^{3}\left(20^{\circ} \mathrm{C} に て\right)$ でるか。但し器壁と空氣との表面傳熱 俰數は器の內外兩面共 $10 \mathrm{kcal} / \mathrm{m}^{2} . \mathrm{hr} .{ }^{\circ} \mathrm{C}$ とし, 外氣は $20^{\circ} \mathrm{C}$ とナる。

〔26]他に何等加熱を行はぬ乾懆器に溫度 $105^{\circ} \mathrm{C}$, 絕對濕度 0.005 の室氣を途入して, 之が乾燥器を去る時溫度 $37^{\circ} \mathrm{O}$, 比較 濕度 $70 \%$ となる。外氣溫が $19^{\circ} \mathrm{C}$ 以下になると空氣の出口附近 の乾燥器內壁に水分が凝缩する。今同じ乾燥能力に對して外氣

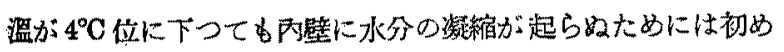
の空氣を何度迄䂆熱して持けばよいか。但し入口の空氣量 $(\mathrm{kg})$

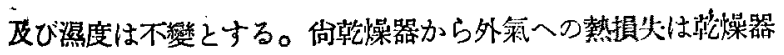
內の空氣の平均㴘度と外氧溫度との差に比例するものとし, 乾 燥物の持出す熱量は無視する。

127]非常に水分の多い固體を皿箱內に愿さ平均 $15 \mathrm{~mm} に$

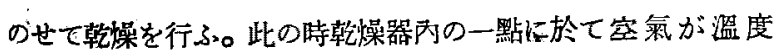
$75^{\circ} \mathrm{C}$, 比較濕度 $30 \%$ であた。此の場合室氣は箱の上下を乾懆 物の面に平行に均一に流してあるが，籍の底面は薄い琙饭をは つてある。之では乾㖨能力が足りないので，箱の底面を目のあ らい格子網にした。然る特前述の一點に於ける畭燥速度は何\%
增加するか。估し網目は充分あらくして，筈の雨面（上下）に 於ける傳熱係數或は水蒸氣の移動倸数は等しいと寸る。網低箱 の場合には固體は算球㳑度にあると假定する。又瀻板底の熱抵

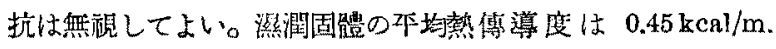
$\mathrm{hr} .{ }^{\circ} \mathrm{C}$ とし，空氮の速度が比較的小なる時及び相常大なる時の 夫夫々に就て計算せよ。前者の場合には圆體加空埭への藏面傳 熱係數を $10 \mathrm{kcal} / \mathrm{m}^{2} . \mathrm{hr} .{ }^{\circ} \mathrm{C}$, 後者の場合には $50 \mathrm{kcal} / \mathrm{m}^{2} \cdot \mathrm{hr} .{ }^{\circ} \mathrm{C}$ とす。

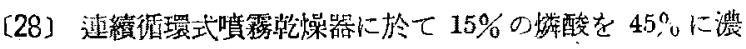
縮寸る際に，唒環夜は原料液と混合して预熱器にて $100^{\circ} \mathrm{C}$ に加 熱した後噴霧室に入る。噴露室を出る液（45\%䗲酸）はその一 部 $1.25 \%$ 。を製品とし，他を很環夜とする。整燥用の空氣は溫度 $30^{\circ} \mathrm{C}$, 濕度 $0.010 \mathrm{~kg} / \mathrm{kg}$ (郣燥空氣) のもの每分 $60 \mathrm{~m}^{3}$ 它適當 に预熱して乾燥室に吹边む。乾燥室を去る室氣住入る時の温度 そ同一にして，且 $45 \%$ 燐酸液と平衡にあるものと做定する。 45\%燐酸には Dühring の法則が䝵用出來るものとし，又乾燥

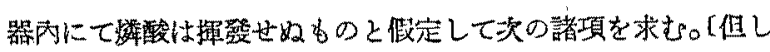
$45 \%$ 䊅酸の比熱は $0.65,45 \%$ 液の $100^{\circ} \mathrm{C}$ 及び $8^{\circ} \mathrm{C}$ に於ける蒸 氮歷は夫々 $650 \mathrm{~mm}, 6 \mathrm{~mm}$ とする了。

（1）空氣及ひ酸の出口の溫度（2）每分の整品，供給原液,

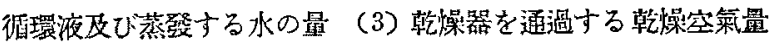
(4) 乾燥器を去る空军の濕度

[29] 內部を 5 段に㤌切つた箱型乾煤器の各段に乾燥㥊を置

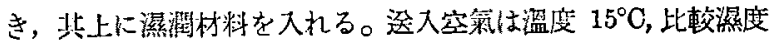

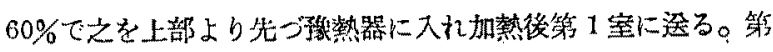
1 空通過後の空氮は加熱器にて再び盕度を上げてから第2室に 揆る。各室通溫後每に加熱器で加熱し，乾燥，加熱を絽返して 第 5 室 (最啳の空)を出る空氣は比較湜度 $50 \%$ となる。宾诵 の再循環は行はない。预熱器及び 4 個の加熱器は水平の鮊付管 群より成り內部には $125^{\circ} \mathrm{C}$ で路縮する水蒸氣が通つてるる。各 室の空氣通墖斷面程は $0.225 \mathrm{~m}^{2}(1.5 \mathrm{~m} \times 0.15 \mathrm{~m})$ で第 1 室に入る 空氣量は $7200 \mathrm{~kg} / \mathrm{m}^{2} . \mathrm{hr}$ である。此䩐燥器の所要全乾懆容量は $170 \mathrm{~kg} / \mathrm{hr}$ で岁るが，各仕切室に於ける材料は同特に同じ樣に

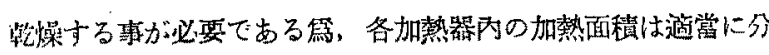

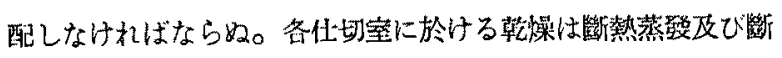
熱却冷に依つて行はれるものとして预熱器及び4 個の加熱器內 の所要管数を求む。各窒の材料は瀑球溫度にあるものと假定

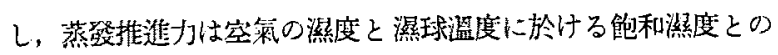
平均差であるとする。叉加熱器肉の各管は長ざ $15 \mathrm{~m} に$ にして長

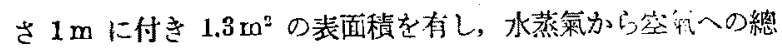
括傳熱係數は $30 \mathrm{kca}^{1} / \mathrm{m}^{2} \cdot \mathrm{hr} .{ }^{\circ} \mathrm{C}$ とする。 


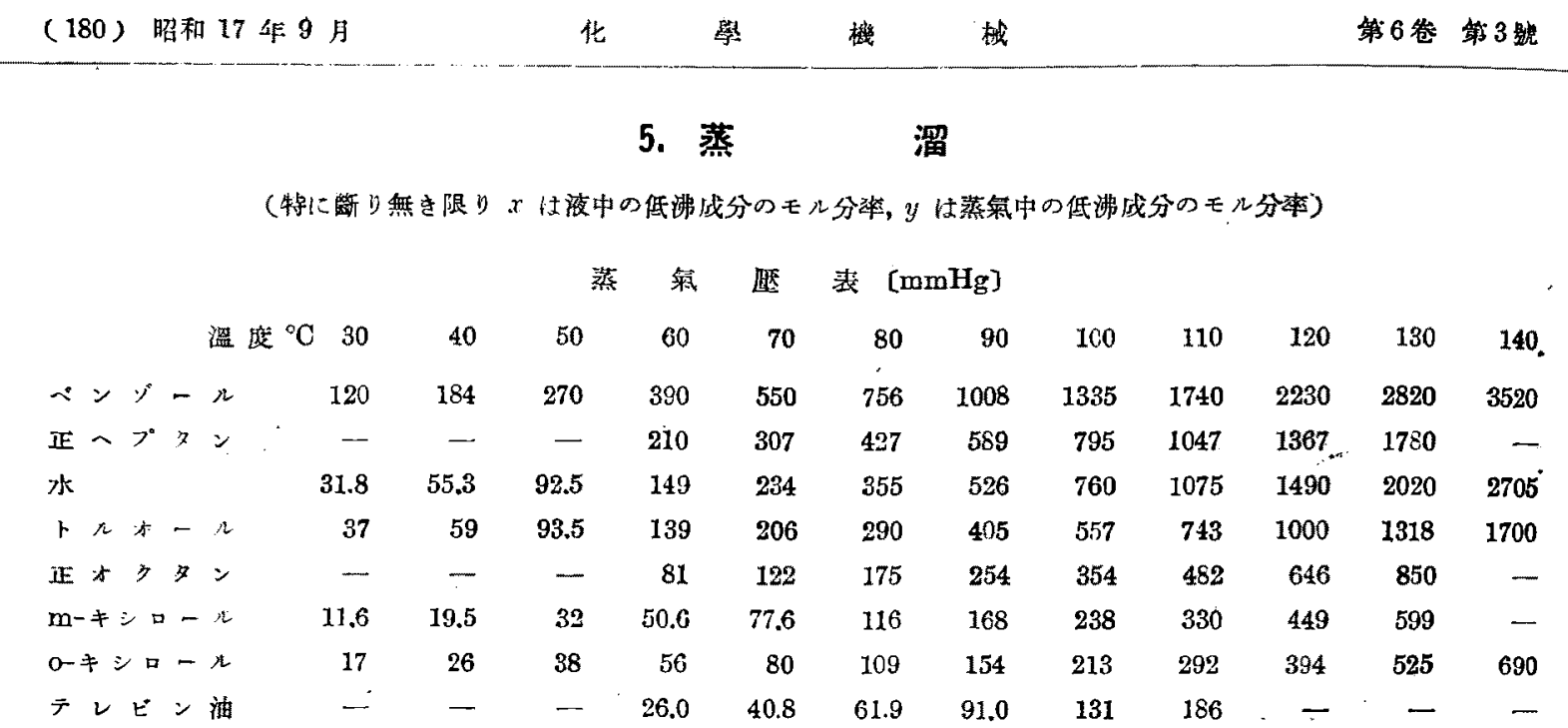

[1]ベンザール・トルオール湿合物がラウル法則に從ふ。 のとして全 $760 \mathrm{mmHg}$ に於ける平衔曲線 $(x, y)$ 及び沸點曲 楾を畫け。

[2] ベンゾール50モル\%, 水 50 モル\%の混合液を 110 ${ }^{\circ} \mathrm{C}$ に熱する時，その全塺及び平衡蒸粱の組成を求を。

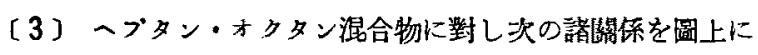
默緅せよ。但しラウルの法則及びダルトンの法則が邀用出來る bのとする。

a) 1 氣壓に於ける4衛曲線 $(x: y)$ b) 沸點曲線 $(x:$ 沸點)

c) 比揮登度 $\propto$ 對 $x$ d) $\propto$ の平均值を用ひて部算せる $x: y$

e) 蒸氣及液中のープタンの重量百分率 $(C: 0)$

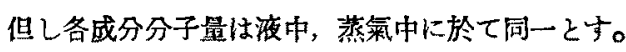

[4]ラウルの啮則に從ふ2 2 成分采の $x-y$ 曲線を畫く場合 に於て，x及び $y$ を夫々モ几分萃にて表はした場合と重量百分 蓉にて表はした場合と曲線の形は如何樣に異るか。

[5] ヘンン゙ール50モル\%, トルオール 30 モル\%，。-キ

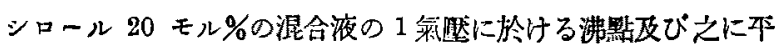
湤なる蒸氣組成を求も。但しラウル法則が成立するいのとす。

[6] $120^{\circ} \mathrm{C}$ に於てベンゾール80モル，水 $20 モ ル \% を$ 含も蒸氣を 1 氣是に保ち乍ら徐冷する時, 最初に凝縮する液の 組成及びその溫度如何。双蒸氮がベンゾール，水各50モル\%の 場合は如何。但しベンジールと水は互に完全に不溶解とす。

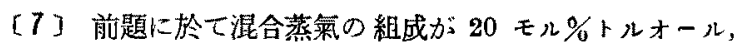
60 モル\%レ゙ンゾール，20モル\%水の場合は如何。
[8] ベンゾール 70 千 ル\%, トルオール 30 そル\%の混合 液を全埾 $760 \mathrm{~mm}$ にて單蒸溜を行ひ, 原液モ几數の $1 / 3$ を蒸 發せしめる時, 溜出物及び殘液の組成如何。但し比揮發度 $\alpha$ を 2.55 とする。

[9]70 モル\%ベンゾールと30モル\%トルオールの混合液 を全㱚が $760 \mathrm{~mm}$ の下で加熱し，原液モル數の $1 / 3$ を蒸發さ せた。此間蒸氣は常に液と接觸せしめおき, 操作後二相を分離

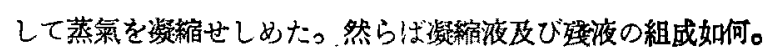

〔10] 5\%(wt) の醋酸水溶液 $1000 \mathrm{~g}$ を單蒸溜して $10 \%$ 液を 得るには何 $\mathrm{g}$ を溜出すればよいか。但し此の渍度範圍に於て4 矢閶保は $y=0.75 x$ にて表はし得るとす。

[11] 95 モル\%酸素を含む液體酸素及び液體空素の混合液 老全盟 1 atm (一定) に於て單蒸溜にかけ，殘液中の酸素が 98 モル\%に達する迄には原夜を何\%（wt) 蒸溜せしむべきかラ ウル法則が成立するおのと假定し，且酸素の沸熙に於ける純酸 素の蒸氣厴と純等素の蒸氣厴之の比は 0.280 とする。

[12] 10 モ $\% \mathrm{NH}_{3}, 90$ モル\%水の混合液を連續蒸溜によ り 28 モ $\% \mathrm{NH}_{2}$ を含む溜出物を得たい。原料 100 モルにつ き下記2法により得らる」溜出物のモル數を求む。
a) 鮞流なしの連絋單蒸溜
b) 理想段 1 段及び矱より成る塔に於ける連結蒸溜

但し原料は $a, b$, 共に沸點の液としてスり，罐の加熱は間接蒸

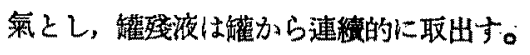

㕛此の範图に於て平衡關係は $y=6.3 x$ で表はされるとする。 $\left(x, y\right.$ は $\mathrm{NH}_{3}$ のモル分率)。 
[13] ベンジール，トルオール；キシロール夫及 $34,33,33$ モル\%の混合物を 1 氣歷に於て蒸溜しペンゾールの95\%を四 收せんとす。a) 單蒸溜の㭙及び b) 本衡蒸溜の㭙二就き溜出 物及び残溜物の組成を求も。但し本蒸溜に於ては䘞溫は約 100 ${ }^{\circ} \mathrm{C}$, 最終温度は約 $130^{\circ} \mathrm{C}$ であり，比掩登度は此雨溫度に於ける

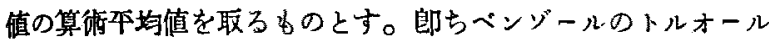
侍する比揮發度 $\alpha_{B r}=2.29$ ，トルオールのキシロールに對す る夫れは $\alpha_{T x}=2.25$ とす。

〔14] $240^{\circ} \mathrm{C}$ に於てステアリン酸の蒸氮嬺は $19 \mathrm{~mm}$ であ る。今 $240^{\circ} \mathrm{C}, 1$ 氣㷴でステアリン酸中に過熱蒸氣を吹込んた。 蒸沙灌及び蒸氣管の保溫完全にして，蒸氣がコンデンサーに至 る迄凝缩の起らぬ樣にするならば溜出するステフりン酸 $1 \mathrm{~kg}$

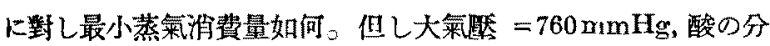
子量 $=284.4$

〔15〕ステアリン酸を $200^{\circ} \mathrm{C}$ て水蒸氣蒸溜する。スチルは湜 樎を防ぐため外部から加熱してるる。スチルを去る蒸氣中の酸 の分医は $200^{\circ} \mathrm{C}$ に於ける純酸の蒸氣压 $(3 \mathrm{mmHg})$ の $70 \%$ に等 しい。消費蒸氣 $1 \mathrm{~kg}$ に就き溜出寸る酸の量 $(\mathrm{kg})$ を全遇の函数 として點制せよ。全整範圍は 760〜25 mm とする。

（16）每時 360 lit のテレビン油を 1 氣避にて水蒸攻蒸溜を 行ふ。外部からは熱の供給を行はぬこととして $0.3 \mathrm{~kg} / \mathrm{cm}^{2}$ (ゲ 一ジ)の水蒸氣每時何 $\mathrm{kg}$ を要するか。但し原料加熱に要する 熱は考へず輻射熱損失は無視する。テレビン油の蒸發潜熱は $74 \mathrm{cal} / \mathrm{g}$ とし，分子量は 136，比重は 0.865 とする。

[17]連續精溜塔に於て 60\%トルオール，40\%ペンリ゙ールの 混合液を每時 $15000 \mathrm{~kg}$ 處理して $97 \%$ ベンゾールの製品を得， 矱液中のトルオールを 98\%ならしめんとす。（以上すぐて重量 $\%$ \%。還流比を 3.5 (製品 1 モルにつき還流を 3.5 モル) とし て头の諸項を求む。但しベンゾール，トルオールの分子蒸發潜 热は $7240 \mathrm{cal} / \mathrm{g}-\mathrm{mol}$ とする。

a) 每時の製品量及び䌯出液量 $(\mathrm{kg})$

b) 理論所要段數及び原料供給段の住固を次の場合について 求む。

1)・原料が涨點にある液の時

2) $20^{\circ} \mathrm{C}$ 液の時 (比熱 $=0.44$ )

3）原料 1 モルの中 $2 / 3$ モルが蒸氣， $1 / 3$ モルが液の時

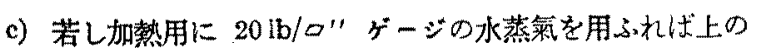
各々の場合に於て其の所变量每時何程か。但し輻射による熱損 失悔無視する。
〔18〕前題に於て $b(1), b(2, b(3)$ の各々の場合につき最 小澴流比及び最小段数を求も。

又仗均段能菜を $60 \%$ とすれば $b(1) ， b(2) ， b(3)$ に於て夫 々段數何程を要寸るか。又供絵段の估置如何。

[19]池筑塔及び底部の罐より成る精溜荅あり。之にて 80

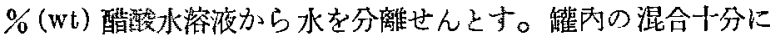

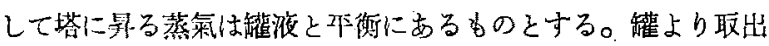

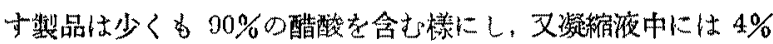

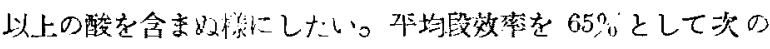
請項を求志。

a) 最小漫流比 b) 最小理論段數 c) 最小濖流比の $30 \%$ 增し の還流比の場合の所姴蛽绦段數

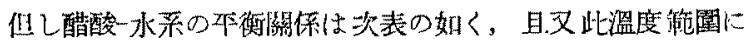
於ける水の平均蒸發潜熱は $536 \mathrm{cal} / \mathrm{g}$ ，醋酸のは $97 \mathrm{cal} / \mathrm{g}$ とす。

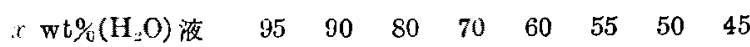

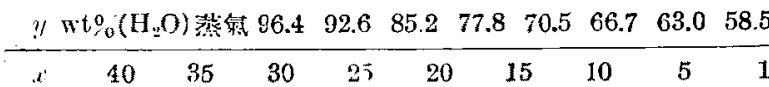

$\begin{array}{llllllllll}y & 53.8 & 48.5 & 42.9 & 36.9 & 30.4 & 23.6 & 16.3 & 8.45 & 2.17\end{array}$

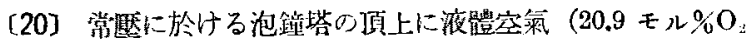
79.1 モル\% $\dot{\mathrm{N}}_{2}$ )を供給して、罐から 99.8 モル\%の ○。がス として取出してるる。此の場合原料中の酸素の $60 \%$ を罐加ら

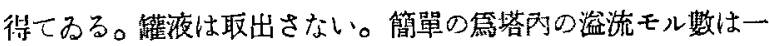
定にして原料モ儿數に等しいものとし次の 2 項を求む。

a) 塔項を去るガス中の $\mathrm{N}_{2}$ のれ昌

b) 所要理論段敕

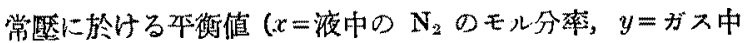
の $\mathrm{N}_{2}$ の๕ル分致) 次の如し

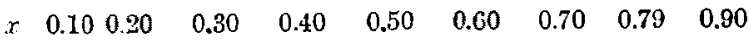

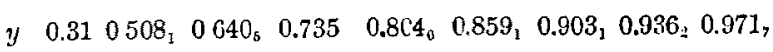

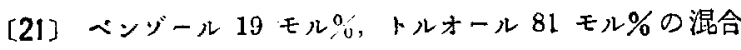
液 $100 \mathrm{~kg} . \mathrm{mol} / \mathrm{hr}$ を攀交換器に邆り，次で之を常塺の分離器

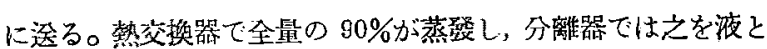
蒸埭に分も，蒸氣のみを精溜塔の供給段に裝入し，海は取除

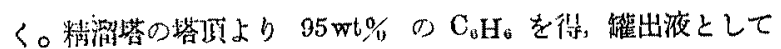
96 モル怘のトルオールを得んとす。一般に行はれる簡單な做 定の下に次の諸項を求む。(1) 還流比を最小值の 1.5 倍とし，

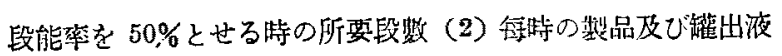
のモル數 (3) 部容最大蒸筷速度を $45 \mathrm{~cm} / \mathrm{sec}$ とする時の塔內

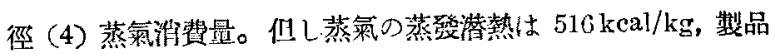

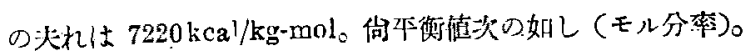




化 學 機

械

$\begin{array}{llllllllllll}x & .915 & .824 & .660 & .513 & .383 & .264 & .158 & .108 & .060 & .014 & 0\end{array}$

$\begin{array}{llllllllllll}y & .964 & .921 & .829 & .725 & .608 & .473 & .319 & .232 & .138 & .034 & 0\end{array}$

[22] ベンゾール，クロルベンゾールの混合物（ペンゾール のモル分率 $=0.545$ ) を理論段 こ個(䌯以外に)を有する荅の最 低段に連續供給する。荅にはスチームコイルに依つて加熱する スチル及び坴凝維器を有する。スチルには充分熱を供給して $I^{\nu} / F\left(I^{\top}\right.$ : 蒸氣のモル數。 $F$ : 原料のモ几數)を 0.855 となる樣

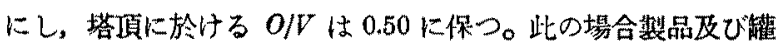

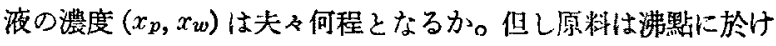
る液として塔に入り，他の邂當なる假定はしてよい。又若し理 論段 4 段にして最下段に供給する洔及び上から 2 段日に供給す る時には $x_{p}, x_{w}$ はどらなるか。平衡值（モル分率次の如し。

$\begin{array}{lllllllll}x & 0.100 & 0.200 & 0.300 & 0.400 & 0.500 & 0.600 & 0.700 & 0.800\end{array}$ $\begin{array}{lllllllll}y & 0.314 & 0.503 & 0.640 & 0.734 & 0.806 & 0.862 & 0.905 & 0 . ? 43\end{array}$

[23] 濃度 $x_{f 1}$ 死U゙ $x_{f_{2}}$ の原料 $F_{1}, F_{\mathrm{z}}[\mathrm{mols} / \mathrm{hr}]$ 各別に 塔に供給する時の3 個の作業線の方程式を作慗せよ。但し製品 濃度は $x_{p}$, 璒液濃度は $x_{w}$, 還流比は $R$, 製品は $P[\mathrm{~mole} / \mathrm{hr}]$, 解液は $\|^{r}[\mathrm{mols} / \mathrm{hr}]$, 濃度はすべてモ几分率にて與へられる。

向上の場合雨原料を混合して濃度 $x_{s m}$ の平均原料とした場合 の 2 個の作業線との閵俰如何。

[24]メタノール85モル\%及び 15 モ\%の濃度の異るュ 種のメタノール水混合夜各々 $100 \mathrm{~kg}-\mathrm{mol} / \mathrm{hr}$ 芝速續蒸溜荅に各 別に適當なる段に供給して $99 \%$ 製品を得，噔液妕のメタノー ルを 1\%ならしめたい。此の時の所要理論段数を求む。但し還 流比は 2.0 とし原料は各段の沸熙にある液とする。

又若し 70 モ\%及び 30 モル\%の 2 喠の原料の場合は如何。 更に各々の場合に於て 2 種の原料を混合供緰する場合は如何。

刃全く同樣の問題をベンソール，トルオール混合物の場合に 就て行人ばどうなるか。但しメタノール・水系の本衡値は次表 の如し。(詳細の表は阿田・加藤，工化，昭9，37，1174 照)

$$
\begin{array}{lrrrrrrr}
x(モ ル \%) & 1.00 & 5.00 & 10.00 & 15.00 & 20.00 & 25.00 & 30.00 \\
y(モ л \%) & 6.65 & 29.90 & 41.77 & 51.69 & 57.94 & 62.68 & 66.55 \\
x(モ ル \%) & 35.00 & 44.00 & 54.45 & 65.30 & 76.45 & 87.96 & 100.00 \\
y(モ ル \%) & 69.95 & 75.00 & 80.00 & 85.00 & 90.00 & 95.00 & 100.00 \\
\text { ヘンゾール・トルオール系に對しては[21] 參照。 }
\end{array}
$$

[25] 40 モル\%トルオール，60 モル\%キシロール混合物よ り 98 モル\%トルオールを96\%司收亲で得んとする。今工場に $0.3 \mathrm{~kg} / \mathrm{cm}^{2}$ ロ゙゙ージの磨蒸氣（飽和）が多量あり，間接加熱に用 ふるには低洫度なるを以て，塔に直接吹込をなす。蒸或は部分
凝縮器で冷却，凝樎水は分離器で除去され，避當なる還流を使 用する。

（1）還流量（トルオール，キシロールの和）と䌘品量（トル オール，キシロールの和）の比が 2.0 なる時の理論段數及原料 供給段を求む。

（2）段の價格及其經費が段の数及塔の兹面積に比例し，㞑水 蒸氣が無價格のものとし，荅頂に於ける蒸氣の速度を一定に保 、つものとするならば，最も適當なる還流及び段數を求む。

[26] ベンジール，トルオール，キシロールを常㻺下で泡鐘 塔により蓮繶蒸溜を行ふ。罐は直火により加熱する。包收圈の 下部に於て藎骕 1 モルにつき溢流が 1.092 モルある。維液の 分析によればペンゾール1.76 チル\%、トルオール62.14 モル\%, キシャール 36.10 モル\%ですつた。然らば a) 雉液の温度，b) 觹上第 1 段の液の組成如何。

〔27〕動的平衡に於て働きつつある蒸溜荅に於て原料供給段 よりす上位のある段に於る蒸氣の組成を分析した所ベンゾール 70 モル\%，トルオール 25\%，m-キシロール5\%であつた。 の荅か理想段として働きつつあるものとして之より1段上の蒸

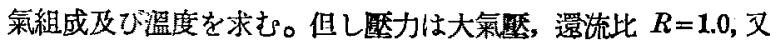
Raoult の法則が成立するとして差支へない。尚現在製品はへ ンゾール 98 モ\%，トルオール 1.5 モ\%，m-キシロール 0.5 モル\%である。

（28） $200 \mathrm{mmHg}$ (絶對)の哐力の下に還流も分樎もなしに 働く䔎續單分溜器に下龍の如き組成の輕油を供給して, 88 重量 $\% の \mathrm{C}_{0} \mathrm{H}_{\text {。 }}$ を含む溜出液を得てるる。ラウルの法則及びがルト ンの法則が成立するとして次の諸項を求む。

a) $100 \mathrm{~kg} / \mathrm{hr}$ の原料につき得らるる溜出液及び排出液の量 ( $\mathrm{kg})$

b) 溜出液と排出液の組成

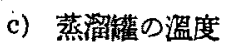

但し下表中バラフィン系炭化水素の蒸氣塬は $50^{\circ}, 60^{\circ}, 70^{\circ} \mathrm{C}$ に於て夫ィ $0.6,1.0,1.6 \mathrm{mmHg}$ とし，他の成分の蒸氣叞は別 丧の如くである。

$$
\begin{aligned}
& \text { ヘンジール } \\
& \text { 卜ルオール } \\
& \text { ロキシロール } \\
& \text { バラフィン柔炭化水素 }
\end{aligned}
$$

$\begin{array}{rr}\text { 原料組成 } & \text { 分子量 } \\ 69 \text { wt\% } & 78 \\ 10 " & 92 \\ 6 & 106 \\ 15 " & 185 \\ & \text { (編輯委員) }\end{array}$

